\title{
Role of Corporate Governance in Increasing the Value Relevance of Earning and Fair Value Measurement of Non-Financial Asset in Indonesia Company
}

\author{
Ananta Dian Pratiwi ; Sutrisno; Aulia Fuad Rahman \\ Department of Accounting, Universitas Brawijaya, Indonesia \\ Email: anantadianp@gmail.com
}

http://dx.doi.org/10.18415/ijmmu.v6i1.507

\begin{abstract}
Accounting information is one of many informations that is used in making decisions by investors. Accounting information has value relevance when the information raises investor reactions, meaning that the information is used for decision making that affects stock prices. This study aimed to examine the value relevance of earning value and the fair value measurement of non-financial assets, along with the role of corporate governance in increasing the value relevance of both informations. This study used 142 companies listed on the Indonesia Stock Exchange during 2012-2017 as study samples. Moedaretd Regression Analysis was used as an analytical tool to test the relationship of study variables. The results showed that earning and the fair value measurement of non-financial assets had value relevance. Both of these informations are considered useful by investors for their decision making. Corporate governance was found to play a role in increasing the value relevance of earning and the fair value measurement of non-financial assets. Corporate governance is able to reduce agency conflicts that can cause information to be biased for investors. The existence of corporate governance provides assurance that informations has been fairly presented to investors, thereby increasing value relevance.
\end{abstract}

Keywords: Value Relevance; Earning; Fair Value Measurement; Nonfinancial Assets; Corporate Governance

\section{Introduction}

Financial statement provides company information related to assets, liabilities, equity, income and expenses including earnings and losses, contributions from and distribution to owners in their capacity as owners, and cash flows. Accounting information is one of the information types that investors need in decision making (Ball and Brown., 1968; Moser., 1989; Barth et al., 2001; Healy and Palepu., 2001, Kothari., 2001). Investors need assurance that each information in the financial statements is useful for their decision making. That is, the information obtained must have value relevance. The value relevance of accounting information indicates quality of accounting information. Barth et al. (2008) states that the higher the value relevance, the higher the quality of accounting information implies.

Barth, Beaver and Landsman (2001) explained value relevance as how informative accounting numbers are for investors and how investors react to the announcement of accounting information. 
Investor reaction can be reflected through stock price movements. When accounting information is presented to investors and stock prices undergo changes, it can prove that the content of accounting information is a very important issue and can be important consideration in the investment decision making process, so it can be said that accounting information is beneficial to investors (Ball and Brown., 1968; Ohlson., 1995; Scott., 2015; Puspitaningtyas., 2012).

The main variable in accounting information on financial statements that is often used as a tool to measure company performance is earning (Ohlson, 1995; Collins et al., 1997). Accounting information in the form of earning was found to have value relevance because of its ability to influence stock prices (Widiastuti and Maiden., 2014; Chandrapala., 2013; Hayati., 2016). The role earnings in determining stock prices has become an important issue in accounting study. Watts and Zimmerman (1986) summarized that most studyers focus on the relationship between changes in earnings and changes in stock prices around the announcement of changes in earnings. Various studies proved that earning is related to price and stock returns (Ball and Brown., 1968; Beaver et al., 1979; Pinasti., 2004).

The novelty of this study is developing value relevance studies by examining the value relevance of accounting information other than earning. The accounting information variable that developed in this study is fair value measurement. Fair value is considered more capable of reflecting the condition of economic values (Barth et al., 1995). Fair value can describe the actual market value. International Accounting Standard Board (IASB) prefers using fair value accounting to conservative accounting methods (Khurana and Kim., 2003; Caprio., 2013). In 2011, IASB issued IFRS 13 "Fair Value Measurement". Enforcement of this standard encourages empirical study to measure the value relevance of fair value measurements. The empirical study that has been done showed that fair value information has value relevance which means it is useful for investor decision making (Song., 2014; Tama-Sweet and Zhang., 2015; Liu., 2016).

However, studies is still focused on the financial or banking industry and financial assets. Barth, Beaver and Landsman (2001) mentioned the need for empirical study regarding the fair value measurement of non-financial assets. Information about the fair value measurement of non-financial assets needs to be tested whether or not it has value relevance. Based on the literature review that has been conducted, studies on the value relevance of the fair value measurement of non-financial assets is still limited. Therefore it is necessary to test the value relevance of the measurement of the fair value of non-financial assets, especially in Indonesia where there is an updated accounting standards regarding the fair value measurement. Dewan Standar Akuntansi Keuangan Indonesia (the Indonesian Financial Accounting Standards Board) issued PSAK 68 about Fair Value Measurement which requires companies to disclose fair value measurements. One of fair value measurement applied to non-financial assets, namely plant, property, equipment (PPE) and investment property. Based on PSAK 68, the fair value measurement of non-financial assets takes into account the ability of market participants to generate economic benefits by using the highest and best use assets or by selling them to other market participants who will use these assets in their highest and best use. Therefore, it is necessary to know the usefulness of the fair value measurement of non-financial assets information for investor in decision making.

Furthermore, the novelty of this study is developing a value relevance model with the addition of corporate governance as an element that is able to increase the value relevance of earning and the fair value measurement of non-financial assets. Accounting information is prepared by management. This information can be risky to investors when management does not deliver the information properly. Earning is believed to be a good predictor that helps investor to predict future earnings and economic events in the future (Belkaoui., 2004; Widiastuti and Meiden., 2014). Investor prefers higher EPS to maximize their wealth. This condition creates a gap for managers to display earnings that can attract investors in financial statements. Investors need assurance that accounting information have been presented fairly. The risk comes not only from earning but also the fair value measurement of non- 
financial assets. Landsman (2007) found that the informative level of information regarding the measurement of fair value was influenced by the number of measurement errors and estimated sources. The risk of this error is certainly avoided by investors because it can affect their decision making. Corporate governance, for example the independence of the audit committee and the presence of financial directors, is one form of control to provide confidence that the information presented in the financial statements is reliable. Corporate governance is expected to increase the value relevance of earnings information and the fair value measurement of non-financial assets.

Based on the explanation above, this study aimed to examine the value relevance of earnings and the fair value measurement of non-financial assets. This study also aimed to prove the role of corporate governance in increasing the value relevance of earning and the fair value measurement of non-financial assets. The results of this study are expected to develop a model of value relevance and add empirical evidence to the fair value measurement.

\section{Hyphoteses Development The Value Relevance of Earning}

The concept of value relevance of accounting information explains how investors react to the announcement of accounting information. This reaction proves that the content of accounting information is important in the process of making investment decisions. Stock price fluctuation is a reflection of investor's reaction to useful information. Accounting earning is an accrual-based accounting product more often regarded as a good predictor to estimate income and economic events in the future (Belkaoui., 2004; Widiastuti and Meiden., 2014). Based on the clean surplus theory, earning is one of the determinants of stock market prices. The expected earning in the future provides sufficient information to calculate the present value in determining the value of the company (Ohlson., 1995). Empirical study conducted by Beaver et al. (1979) showed that annual earnings announcements contain information that is relevant and useful in valuing securities. Pinasti (2004) found that earnings per share form the basis of stock prices. Widiastuti and Maiden (2013), Chandrapala (2013), and Hayati (2016) found that earning is one of the accounting information that affects stock prices. Based on these explanations, this study proposes the first hypothesis as follows: Earning has a positive effect on stock prices.

\section{The Value Relevance of the Fair Value Measurement of Non-Financial Assets}

Fair value measurement is considered to reflect the economic conditions of the company better than historical values (Barth et al., 1995). Empirical studies have been conducted to test the value relevance of fair value measurements. Song (2014) used US financial companies and found that fair value measurement has a benefit to investors' decision making. Tama-Sweet and Zhang (2015) measured the value relevance of the three levels of fair value of assets during the period of the 2008-2009 financial crisis and compare them with the normal economic period of 2012-2013. Study focused on financial assets of the banking industry and showed that fair value disclosures were useful information for investor decision making. These results are in line with Liu (2016) who tested the value relevance of fair value measurements on financial products. The fair value measurement of non-financial assets is expected to have benefits for investors because of the existence of non-financial assets as the company's operational assets. The measurement of the fair value of non-financial assets can provide investors with information about the market value of these assets and provide guarantees of stock returns. Based on this, the second hypothesis proposed is as follows: The fair value of non-financial assets has a positive effect on stock prices. 


\section{The Role of Corporate Governance in Increasing the Value Relevance of Earning}

Earning is believed to be significant predictor that helps in estimatin future earnings and economic events in the future (Belkaoui., 2004; Widiastuti and Meiden., 2014). Company's ability to generate earnings will make investors interested in investing in the company. Higher earning has more chance to increase investor preference in investing in the company. This creates a gap for managers to display earnings that can attract investors in financial statements (Jensen and Meckling., 1976). Therefore, the existence of a corporate governance mechanism is expected to be able to prevent agents from deviating so that the earning information displayed in the financial statements can be relevant and fairly presented, which is used in investor decision making. Based on this, the third hypothesis proposed is: Corporate governance increases the relationship between earnings and stock prices.

\section{The Role of Corporate Governance in Increasing the Fair Value Measurement of Non-Financial Assets}

The relationship between the fair value measurement of nonfinancial assets and stock prices needed to be tested with moderation of corporate governance. This was done to find out the magnitude of changes in value relevance with regard to asset measurement depending on the strength of the corporate governance mechanism. Corporate governance, for example the independence of the audit committee and the existence of financial directors' expertise, can increase the value relevance of the measurement of nonfinancial assets (Yao., 2014). Tama-Sweet and Zhang (2015) showed that corporate governance has a positive influence on banking stock prices. That is, corporate governance can increase the usefulness of information about fair value for investor decision making. The results of this study are in line with Song et al. (2010) who found that the corporate governance mechanism has an effect on the relevance of the value of information on the measurement of the fair value of financial assets. The low governance mechanism can reduce the value relevance of fair value measurements. Based on this, the fourth hypothesis proposed is: Corporate governance increase the relationship between the fair value of nonfinancial assets and stock prices.

\section{Research Design}

This study used secondary data from all companies listed on the Indonesia Stock Exchange (IDX). Population was chosen because the company has issued financial statements based on the Financial Accounting Standards (PSAK) which include PSAK 16- Fixed Assets and PSAK 58-Fair Value Measurement. This study used a purposive sampling method to determine the sample used to test the hypothesis. First, study used companies that consistently issued financial reports in the period 2012-2017. Companies registered after 2012 were excluded from the sample. Second, 91 companies in the financial sector were excluded because they had a different business structure than non-financial companies. Third, 210 companies that have negative earnings were excluded because they are irrelevant. Fourth, 18 companies had missing data, so it were excluded. Table 1 describes the procedure for selecting samples.

The dependent variable is VALUE RELEVANCE (VR) which is proxied through the stock price. The stock price used is stock prices after three months of fiscal year (Adhani and Subroto., 2013). Based on the regulations of the Financial Services Authority, public companies must submit financial statements a maximum of three months after closing the book. Therefore, the stock price after three months of closing book is considered capable of reflecting the reaction of investors to accounting information that can reflect value relevance. 
Table 1 Sample selection procedure

\begin{tabular}{lc}
\hline & Firm-Year Observations \\
\hline Original Observation & 3,654 \\
Less: & \\
Financial Sector & 546 \\
Listed After 2012 & 852 \\
Negative EPS & 1,260 \\
Missing Data & 108 \\
Final Sample & 888 \\
\hline
\end{tabular}

Two independent variables are used in this study, namely EARNING and FAIR VALUE. The independent variable EARNING is measured based on earnings per share (Collins et al., 1997; Carnevale et al., 2009; Adhani and Subroto., 2013). Earnings per share is a ratio that shows how much earning is obtained by investors or shareholders per share (Darmadji and Fakhruddin., 2011). Earnings per share are net income after taxes which have been deducted by dividends divided by the number of shares outstanding. Meanwhile, FAIR VALUE is variable to measure the fair value measurement of nonfinancial asset. It is measured by a dummy variable, which is 1 if the company chooses to measure nonfinancial assets with fair value in year $t$, and 0 otherwise.

CORPORATE GOVERNANCE (CG) is moderating variable. The measurement of corporate governance mechanisms uses an index based on the Corporate Governance Scorecard by the IFC Corporate Governance Group. The index has five principles of corporate governance that must be fulfilled by the company. Each principle contains points that are worth 1 if applied and 0 if not applied. The final CORPORATE GOVERNANCE value is the number of percentages based on the five principles of corporate governance as follows:

1. Rights of shareholders (15\%)

2. Equitable treatment of shareholders $(20 \%)$

3. Role of stakeholders (5\%)

4. Disclosure and transparency (30\%)

5. Responsibilities of the board (30\%)

This study uses Moderated Regression Analysis (MRA) analysis technique. MRA is a special application of multiple linear regression where the regression equation contains an element of interaction (multiplying two or more independent variables). This interaction test is used to determine the extent to which the interaction of corporate governance can influence the relevance of earnings values and the measurement of the fair value of non-financial assets. In this study, data was processed using computer software, namely SPSS 16.0. The results of the regression analysis are in the form of coefficients for each independent variable. The multiple linear regression equation in this study is as follows:

$$
\mathrm{VR}=\alpha+\beta_{1} E+\beta_{2} F V+\beta_{3} C G+\beta_{4} E \cdot C G+\beta_{5} F V \cdot C G+\varepsilon
$$

Notes:

VR: value relevance

$\alpha$ : konstanta

$\beta_{1}, \beta_{4}$ : regression coefficient

E: earning

FV: fair value measurement of non-financial asset

CG: corporate governance 


\section{Result and Discussion}

The study model has been tested in classical assumptions tes to ensure that the model can be used to predict the relationships proposed in the study. The test shows that the model used has fulfilled the classic assumptions of which data are normally distributed, non-autocorrelated, non-multicollinearity, and non-heterocedasticity. MRA is used to test the relationship of variables at $\alpha=5 \%$ with the following results:

Table 2 Results of moderated regression analysis

\begin{tabular}{llll}
\hline Variable & $\begin{array}{l}\text { Predicted } \\
\text { Sign }\end{array}$ & Coefficient & t-Stat \\
\hline Constant & & 189.927 & 2.702 \\
EARNING & + & 0.747 & $34.064^{*}$ \\
FAIR VALUE & + & 0.101 & $4.589^{*}$ \\
Corporate Governance: & & & \\
EARNING*CORPORATE GOVERNANCE & + & 0.419 & $2.566^{*}$ \\
FAIR VALUE*CORPORATE GOVERNANCE & + & 0.396 & $1.999^{* *}$ \\
& & & 0.623 \\
R Square & & & 0.622 \\
Adjusted R Square & & & \\
\hline
\end{tabular}

*Significant at $\alpha=1 \%$ (two-tailed test)

**Significant at $\alpha=5 \%$ (two-tailed test)

Table 2 shows that the Adjusted R Square value is 0.622 . This value indicates that $62.2 \%$ value relevance (stock price) can be explained by two independent variables, namely earning and the measurement of the fair value of non-financial assets, and the interaction between corporate governance and the two independent variables. While the remaining $37.8 \%$ is influenced by other variables not included in the study model.

\section{The Value Relevance of Earning}

Table 2 shows that EARNING have $\beta$ coefficient of 0.747 . This number is greater than others, so EARNING has a dominant influence on the dependent variable. This result supports clean surplus theory of which states that earning is one of the determinants of stock prices. Earning is important information for investors because it can act as a good predictor of future income and economic events (Belkaoui., 2004; Widiastuti and Meiden., 2011). Ohlson (1995) explained that investors use earnings information to calculate the present value of the value of the company.

Earnings significance value indicates a number smaller than $\alpha=0.05$ and a positive regression coefficient, so the first hypothesis is accepted that Earning has a positive effect on stock prices. That is, an increase in Earning increases stock prices. The influence of stock prices explains that earnings announcements react to stock prices. The reaction to stock prices shows the usefulness of earning information for investors. Earning described through EPS has value relevance because it is measurement of company's ability to generate net income on each share (Ball \& Brown., 1968). This information is valuable to investors for stock purchase decisions. This test results support the empirical study conducted by Beaver et al. (1979), Widiastuti and Maiden (2013), Chandrapala (2013), and Hayati (2016) which showed that annual earnings announcements contain information that is relevant and useful in valuing 
securities. Measurement of earnings through EPS is also supported by Pinasti (2004) who found that earnings per share form the basis of stock prices.

\section{The Value Relevance of the Fair Value Measurement of Non-Financial Assets}

Table 2 shows FAIR VALUE significance values smaller than $\alpha=0.05$ and positive regression coefficients, so the second hypothesis is accepted that the measurement of the fair value of non-financial assets has a positive effect on stock prices. Companies that disclose non-financial assets using fair value can increase stock prices. This result supports empirical study conducted to examine the relevance of the value of fair value measurements. Song (2014), Tama-Sweet and Zhang (2015) and Liu (2016) have tested the value relevance of the measurement of the fair value of financial assets. The results of the study regarding the measurement of the fair value of non-financial assets develops empirical study regarding the value relevance of fair value measurements. The measurement of fair value of non-financial assets also has value relevance, not only in financial assets.

The existence of a fair value measurement in the company is very important. Fair value measurement can reflect the economic conditions of a company better than historical values (Barth et al., 1995). The fair value measurement of non-financial assets has value relevance, meaning that this information is useful for decision making for investors because of the existence of non-financial assets as the company's operational assets. The measurement of the fair value of non-financial assets can provide investors with information about the market value of these assets and provide guarantees of stock returns.

\section{The Role of Corporate Governance in Increasing the Value Relevance of Earning}

Table 2 shows the results of the interaction between CORPORATE GOVERNANCE and EARNING on stock prices. The significance value is less than $\alpha=0.05$ and the positive regression coefficient proves that the third hypothesis is accepted. Corporate Governance can increase the relationship between earnings and stock prices. This result can explain that corporate governance is able to increase the value relevance of earning.

Corporate governance is a mechanism that is formed to reduce agency conflict. Earning is believed to be a means of prediction that helps predict future earnings and economic events in the future (Belkaoui., 2004; Widiastuti and Meiden., 2011). The higher the earning generated, the higher the chance of company to be preferred by investors. This creates a gap for managers to display earnings that can attract investors in financial statements (Jensen and Meckling., 1976). Earnings information can be ambiguous which can reduce its usefulness in the eyes of investors. The existence of corporate governance is able to prevent acts of deviating agents so that earning information displayed in financial statements can be relevant. Investors gain confidence that earnings information has been presented fairly so that the relevance of earnings values can increase.

\section{The Role of Corporate Governance in Increasing the Fair Value Measurement of Non-Financial Assets}

Table 2 shows the interaction between CORPORATE GOVERNANCE and FAIR VALUE on Stock Prices. The significance value is less than $\alpha=0.05$ and the positive regression coefficient proves that the fourth hypothesis is accepted. Corporate Governance increase the relationship between Fair Value and Stock Prices. These results indicate the role of corporate governance in increasing value relevance of fair value measurement. 
Landsman (2007) found that the informative level of information regarding the measurement of fair value was influenced by the number of measurement errors and estimated sources. There is a risk faced by investors when obtaining information about measuring the fair value of non-financial assets. Such information may be inadequate, affecting investor decisions. The existence of corporate governance can overcome this risk. Corporate governance mechanisms, such as the presence of audit committees and financial experts, can improve the quality of fair value measurement information. The results of the study are in line with Yao (2014) that corporate governance is able to increase value relevance from measuring non-financial assets (Yao., 2014). Song et al. (2010) who found that the corporate governance mechanism has an effect on the relevance of the value of information on the measurement of the fair value of financial assets. The results of the study are also in line with Tama-Sweet and Zhang (2015) showing that corporate governance has a positive influence on banking stock prices. That is, corporate governance can increase the usefulness of information about fair value for investor decision making.

\section{Conclusion}

Financial statements are one of the sources of information used by investors for decision making. Accounting information in financial statements is considered useful when the information can influence investor decisions. The usefulness of information can be called value relevance. When information is presented and share price movements occur, the information has value relevance. This study aimed to examine the relevance of earnings values and the measurement of the fair value of non-financial assets. Corporate governance is chosen as a moderator that can increase the relevance of earning values and the measurement of the fair value of non-financial assets.

Testing of 142 companies listed on the Indonesia Stock Exchange during 2012-2017 showed that information about earnings and the measurement of the fair value of non-financial assets have value relevance. Investors assess that both information is useful for their decision making. Earnings announcements can increase stock prices. Similarly, companies that report their non-financial assets at fair value can increase their stock prices. The existence of corporate governance, in fact, cannot be ignored. Corporate governance is proven to increase the value relevance of earning and the fair value measurement of non-financial assets. Corporate governance can be a mechanism to reduce agency conflicts that can impose information bias and harm investors. Companies with good governance can provide assurance that earnings information and the fair value measurement of non-financial assets have been fairly presented so that value relevance increases. The increasing of value relevance shows investor's belief that this information are useful for decision making.

\section{Limitation and Suggestion}

Study has limitations because some companies do not have complete data, thereby reducing the number of samples. Testing the value relevance of fair value measurement on non-financial assets in this study is still limited because it is done by classifying companies that disclose fair value and not. Further study can develop a test of value relevance by comparing the value relevance of each level of fair value measurement. Future study can focus on whether companies that use information on measuring fair value at level 1 have a higher level of relevance than level 2 or level 3.

Further study can also consider environmental and cultural conditions that can affect corporate governance. Indonesian companies adhere to a two-tier system which certainly affects the corporate governance system. Subsequent study can be conducted in countries with a unitary board system to test whether differences in corporate governance can affect the relevance of earnings values and the measurement of the fair value of non-financial assets. 


\section{References}

Adhani, Y. S., \& Subroto, B. (2013). Relevansi Nilai Informasi Akuntansi. Jurnal Ilmiah Mahasiswa FEB, 2(2).

Ball, R. dan Brown, P. (1968). An Empirical Evaluation of Accounting Numbers. Journal of Accounting Research, 6: 159-177.

Barth, M.E., Beaver, W. H., dan Landsman, W. R. (2001). The Relevance of the Value Relevance Literature for Accounting Standardsetting: Another View. Journal of Accounting and Economics, 31: 77-104.

Landsman, W.R., dan Lang, M.H. (2008). International Accounting Standards and Accounting Quality. Journal of Accounting and Economics, XLVI: 467-498.

, Wahlen, J.M. (1995). Fair Value Accounting: Effects on Banks' Earnings Volatility, Regulatory Capital, and Value of Contractual Cash Flows. Journal of Banking and Finance, 29: 577-605.

Beaver, W. H., Clarke, R., \& Wright, W. F. (1979). The association between unsystematic security returns and the magnitude of earnings forecast errors. Journal of accounting research, 17: 316-340.

Riahi-Belkaoui, A. (2004). Accounting theory. Cengage Learning EMEA.

Caprio, G. (2013). Handbook of Key Global Financial Markets, Institutions, and Infrastructure. Williamstown: Academic Press.

Carnevale, C., Giunta, F., \& Cardamone, P. (2009). The Value Relevance of Social Report. The European Financial Management Association.

Chandrapala, P. (2013). The value relevance of earnings and book value: The Importance of ownership concentration and firm size. Journal of Competitiveness, 5(2): 98-107.

Collins, D. W., Maydew, E. L., \& Weiss, I. S. (1997). Changes in the value-relevance of earnings and book values over the past forty years. Journal of accounting and economics, 24(1): 39-67.

International Finance Corporation. (2014). Corporate Governance Scorecard. NW Washington.

Darmadji, T., \& Fakhruddin, H. M. (2011). Pasar Modal Di Indonesia Edisi 3. Jakarta: Salemba Empat.

Hayati, M. (2016). Value Relevance of Accounting Information Based on PSAK Convergence IFRS (Manufacture Firms in Indonesia). Jurnal Praktik Bisnis, 5(1): 67-78.

Healy, P. M., \& Palepu, K. G. (2001). Information asymmetry, corporate disclosure, and the capital markets: A review of the empirical disclosure literature. Journal of accounting and economics, 31(1-3): 405-440.

International Accounting Standar Board. (2011). 13: Fair Value Measurement.

Jensen, M. C., \& Meckling, W. H. (1976). Theory of the firm: Managerial behavior, agency costs and ownership structure. Journal of financial economics, 3(4): 305-360. 
Khurana, I. K., \& Kim, M. S. (2003). Relative Value Relevance of Historical Cost vs. Fair Value: Evidence from Bank Holding Companies. Journal of Accounting and Public Policy, 22: 19-42.

Kothari, S.P. (2001). Capital Markets Research in Accounting. Journal of Accounting and Economics, 31 : 105-231.

Landsman, W.R. (2007). Is Fair Value Accounting Information Relevant And Reliable? Evidence from Capital Market Research. Accounting and Business Research, 37: 19-30.

Liu, S. (2016). Fair Value, Auditor Specialization, and the Value Relevance of Financial Products. Conference Paper.

Moser, D.V. (1989). The Effects of Output Interference, Availability, and Accounting Information on Investors' Predictive Judgments. The Accounting Review, LXIV: 433-448.

Ohlson, J.A. (1995). Earnings, Book Value and Dividends in Equity Valuation. Contemporary Accounting Research, 11: 661-667.

Pinasti, Margani. (2004). Faktor-Faktor yang Menjelaskan Variasi Relevansi-Nilai Informasi Akuntansi: Pengujian Hipotesis Informasi Alternatif. Simposium Nasional Akuntansi VII: 738-753.

Puspitaningtyas, Z. (2012). Relevansi Nilai Informasi Akuntansi dan Manfaatnya Bagi Investor. Ekuitas: Jurnal Ekonomi dan Keuangan, 16: 164 -183.

Scott, W.R. (2015). Financial Accounting Theory. Canada: Prentice Hall.

Song, X. (2014). Value Relevance of Fair Values-Empirical Evidence of the Impact of Market Volatility. Accounting Perspectives, 14: 91-115.

Tama-Sweet, I. \& Zhang, L. (2015). The Value Relevance of Fair Value Financial Assets During and After the 2008 Financial Crisis: Evidence from the Banking Industry. Journal of Finance and Bank Management, 3: 11-24.

Watts, R. L. \& J. Zimmerman. (1986). Positive Accounting Theory. New Jersey: Prentice-Hall.

Widiastuti, N. P. E., \& Meiden, C. (2014). Relevansi Nilai Laba dan Buku Ekuitas dengan Dimoderasi oleh Aspek Perpajakan. Media Riset Akuntansi, 3(1): Hal-105.

Yao, D.F., Percy, M., \& Hu, F. (2014). Fair Value Accounting for Non-Current Assets and Audit Fees: Evidence from Australian Companies. Journal of Contemporary Accounting \& Economics, 1-15.

\section{Copyrights}

Copyright for this article is retained by the author(s), with first publication rights granted to the journal.

This is an open-access article distributed under the terms and conditions of the Creative Commons Attribution license (http://creativecommons.org/licenses/by/4.0/). 